\title{
Evaluating the efficacy of potential fungicide-adjuvant combinations for control of myrtle rust in New Zealand
}

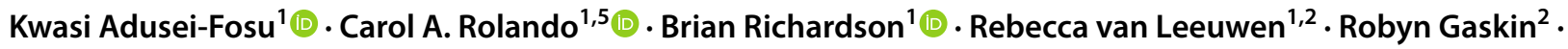 \\ Martin K.-F. Bader ${ }^{3,6}$ (1) Amin K. Pathan ${ }^{4}$
}

Received: 8 January 2021 / Accepted: 16 August 2021 / Published online: 31 August 2021

(c) The Author(s) 2021

\begin{abstract}
Myrtle rust is a serious fungal disease caused by Austropuccinia psidii affecting a number of Myrtaceae species in New Zealand and elsewhere. Control with fungicides or biologicals provides a mechanism to reduce the build-up of inoculum in the short-term while other strategies are being developed or deployed for long-term management. This study evaluated the efficacy of fungicides for control of myrtle rust under controlled conditions and identified adjuvants that would promote spreading of fungicidal active ingredients across the leaf surface. The spread of fungicide on detached M. excelsa leaves was assessed by applying three different adjuvants in combination with seven fungicides. Subsequently, M. excelsa plants were treated with three fungicides/mixes, (azoxystrobin + epoxiconazole, triademinol or a natural tea-extract) at a single rate followed by inoculation with $A$. psidii urediniospores on day $0,7,14$ or 21 days after spraying. The response to infection in M. excelsa plants based on different inoculation timings at days 0,7 and 21 significantly differed among fungicide treatments. The fungicide azoxystrobin + epoxiconazole was the most effective with infections significantly lower on the adaxial leaf surface than abaxial, despite good surface coverage of fungicide being achieved on both leaf surfaces. There were significant differences among fungicides based on the proportion of infected leaves on M. excelsa plants. Day 21 postspray inoculation indicated a significant interaction between inoculation time and fungicide on leaf disease ratings. However, this was not the case at either 28 or 35 days post-inoculation. This research contributes to fungicide options for myrtle rust control in New Zealand.
\end{abstract}

Keywords Austropuccinia psidii $\cdot$ Myrtle rust $\cdot$ Myrtaceae $\cdot$ Inoculation $\cdot$ Fungicides $\cdot$ Adjuvants

Kwasi Adusei-Fosu

Kwasi.adusei-fosu@scionresearch.com

1 Scion, Titokorangi Drive, Private Bag 3020, Rotorua 3046, New Zealand

2 Plant Protection Chemistry NZ Ltd (PPC-NZ), PO Box 6282, Rotorua 3043, New Zealand

3 School of Science, Auckland University Technology (AUT), 34 St. Paul Street, Auckland Central 1010, New Zealand

4 Ministry for Primary Industries, PO Box 1340, Rotorua, New Zealand

5 Present Address: Department of Conservation, PO Box 1146, Rotorua 3040, New Zealand

6 Present Address: Department of Forestry and Wood Technology, Linnaeus University, P G Vejdes väg, 35195 Växjö, Sweden

\section{Introduction}

The biotrophic myrtle rust pathogen (Austropuccinia psidii), first reported in Brazil (Chardón and Toro 1934; Kern et al. 1933; Lindquist 1982), has spread to many countries including Japan (Kawanishi et al. 2009), Australia (Carnegie et al. 2010) and New Caledonia (Giblin 2013), USA (Rayachhetry et al. 1997), Jamaica (MacLachlan 1938), South Africa (Roux et al. 2013), Indonesia (McTaggart et al. 2016), and Singapore (Du Plessis et al. 2017), and is also widespread throughout South and Central America (Coutinho et al. 1998; Ross-Davis et al. 2013). Members of the plant family Myrtaceae are predominantly infected by A. psidii (Carnegie et al. 2010; Carnegie and Lidbetter 2012) with infections often leading to deformation of the leaves, leaf dieback and subsequent defoliation leading to tree death (Coutinho et al. 1998; Glen et al. 2007; Uchida et al. 2006). 
Myrtle rust was first detected in New Zealand in 2017 (Beresford et al. 2018). With about twenty-nine native Myrtaceae species (six genera) and a large number of exotic Myrtaceae (Buys et al. 2016), myrtle rust is seen as a significant threat to both indigenous ecosystems and plant industries in New Zealand. Many of these Myrtaceae, including the iconic pōhutukawa (Metrosideros excelsa), mānuka (Leptospermum scoparium) and ramarama (Lophomyrtus bullata) are known to be susceptible to myrtle rust (Ganley and Beresford 2018).

Options for long-term management of myrtle rust in New Zealand, at least for highly susceptible species, include the identification of resistant genotypes and development of biological controls. However, more immediate options, such as the use of fungicides or biocides, are needed to manage the disease on plant species (or iconic individuals) that are important for conservation, cultural or economic reasons. There have been relatively few trials testing fungicides against myrtle rust under field conditions (Ferrari et al. 1997; Goes et al. 2004; Zauza 2008; Furtado and Moraes 2011; Masson et al. 2013). In Australia, and a number of South American countries, chemical control was evaluated (Ruiz et al. 1991; Alfenas et al. 1993; Carnegie et al. 2010; Martins et al. 2011) and several fungicide groups, such as demethylation inhibitors (DMI) and strobilurins (Masson et al. 2013), were shown to be effective. In neighbouring countries, such as New Caledonia, most of the infected myrtaceae and potential host plants were mechanically removed, and their cultivation banned as a method of controlling the pathogen (Giblin 2013).

At the time of this study, there was virtually no information on the efficacy of fungicides against myrtle rust on susceptible New Zealand Myrtaceae species. The exception was one controlled, artificial inoculation study conducted in Australia (Pathan et al. 2020) that evaluated the efficacy of a range of fungicide mixtures (tebuconazole + trifloxystrobin, cyproconazole + azoxystrobin, fosetyl aluminium, triforine, triadimenol, oxycarboxin, copper and tebuconazole) for control of A. psidii on two iconic New Zealand species, $L . x$ ralphii and M. excelsa, sourced from New Zealand. Pathan et al. (2020) focused on evaluating the impacts of fungicide application rate $(\times 2)$, frequency (single or double), and timing (pre- or post-infection) of application on host species infection. Pathan et al. (2020) reported that the most effective fungicides on both species were those that included both a demethylation inhibitor and strobilurin in the mix, especially tebuconazole + trifloxystrobin and cyproconazole + azoxystrobin. Furthermore, the timing of application was found to significantly affect bio-efficacy, with applications made 7 days before inoculation or 7 days after inoculation being generally the most effective (Pathan et al. 2020). However, according to these authors the rate of fungicide application was not significant for both host species. Pathan et al. (2020) also observed higher infection on lower leaf surfaces compared with the upper leaf surfaces of plants and attributed this to the spray method used in their study. These researchers used a Generation III Research Sprayer booth which applied the fungicide above the plant canopy which possibly resulted in lower coverage of fungicide on the abaxial leaf surface. Based on findings from Pathan et al. (2020) and a comprehensive myrtle rust control review (Chang et al. 2018), some promising fungicides were identified and recommended for further testing in New Zealand conditions.

Agrochemical adjuvants are commonly used to improve efficacy of systemic pesticides on the target species, typically by improving adhesion and/or retention of the pesticide on the leaf surface or by increasing the penetration of the pesticide into the plant (Zabkiewicz 2000). If effective, and properly selected through laboratory and field studies, adjuvants can also extend the interval between sprays (Gent et al. 2003). The only documented research where fungicides have been mixed with an adjuvant (Agral Spray) for control of myrtle rust, was a fungicide trial carried out under field conditions in Australia (Horwood et al. 2013). However, the authors did not report on the effect of the adjuvant on spread area or leaf penetration and therefore it is not possible to determine whether or not the adjuvant improved the efficacy of the treatment.

Building on previous work (Chang et al. 2018; Pathan et al. 2020), the purpose of this study was, for the first time in New Zealand, to evaluate a range of fungicides for efficacy against myrtle rust on an iconic Myrtaceae, M. excelsa. Considering the importance of optimum spread of droplets on leaf surfaces during fungicide application, adjuvants were also tested to identify which class of adjuvant would best promote spreading across the leaf surface. The adjuvant that produced the best spread was selected and subsequently used in the efficacy trial. Thus, a secondary objective was to identify the most suitable adjuvant for ensuring good coverage of the fungicides over the leaf surfaces of the target plant species. Suitable fungicide application methods and inoculation protocols were also developed.

\section{Materials and methods}

All work involving the pathogen, A. psidii was carried out under physical containment (PC1) facilities due to New Zealand biosecurity regulations in place at that time. 


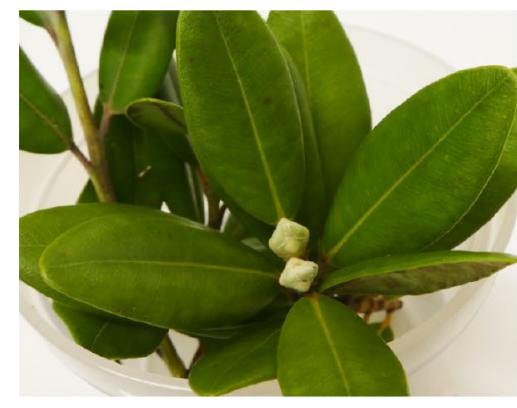

Plant 1, adaxial

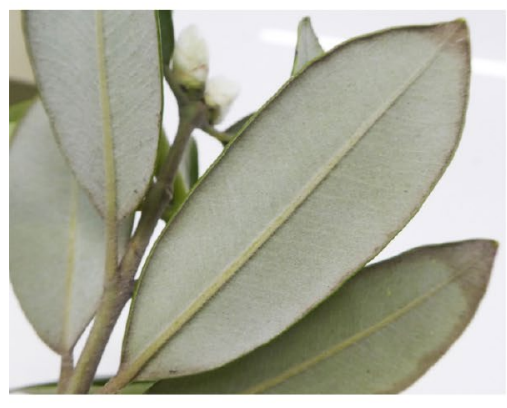

Plant 1, abaxial

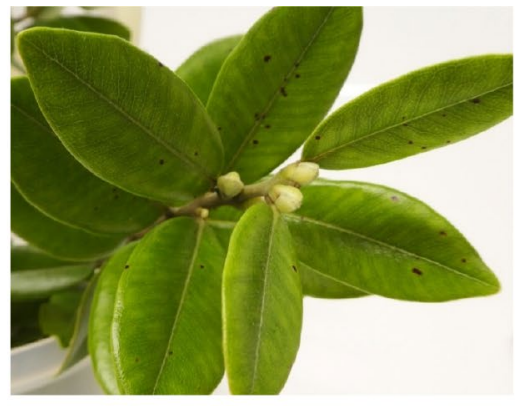

Plant 2, adaxial

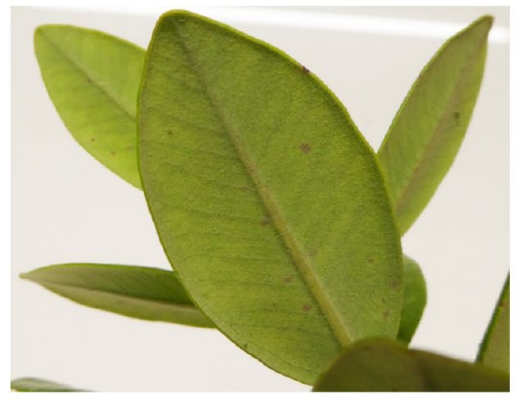

Plant 2, abaxial

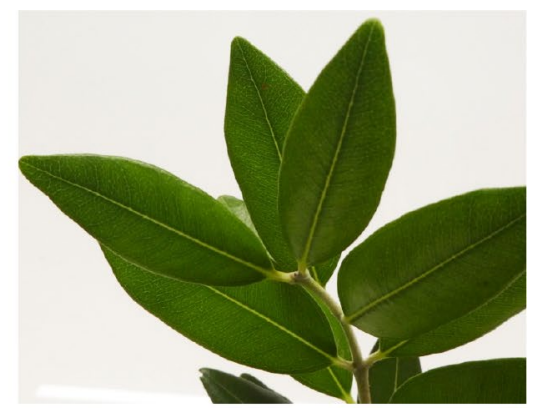

Plant 3, adaxial

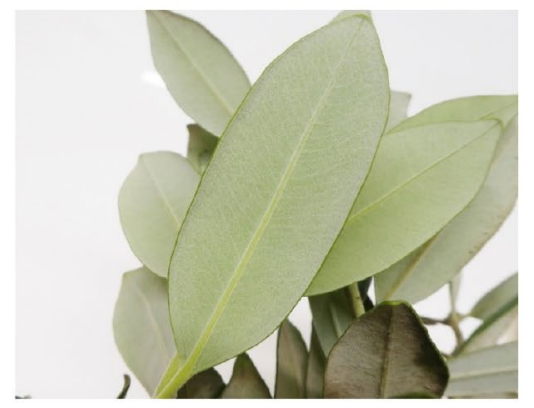

Plant 3, abaxial

Fig. 1 Adaxial (upper) and abaxial (lower) leaf surfaces of M. excelsa plants 1, 2 and 3, used for spread area determination

\section{Determination of droplet spread for adjuvant-fungicide combinations}

\section{Adjuvant selection trials}

Three healthy $M$. excelsa trees were selected in separate locations in Rotorua, New Zealand environs and labelled as 1, 2 and 3. Multiple fresh shoots bearing the youngest healthy foliage were harvested as shown in Fig. 1 from each tree in the early morning hours. The fresh shoots were wrapped in wet-paper towels and kept cool in chilli bins until transported to the laboratory. In the laboratory, stems were kept moist in a beaker of water and maintained at $20^{\circ} \mathrm{C}$ until use.

Three typical adjuvant classes used in fungicide sprays were selected for testing as follows:
- Actiwett® (Etec Crop Solutions, New Zealand), a nonionic, $950 \mathrm{~g} \mathrm{~L}^{-1}$ linear alcohol ethoxylate, used at 0.05 and $0.075 \%$;

- Hasten ${ }^{\mathrm{TM}}$ (BASF New Zealand Ltd), an esterified seed oil, $704 \mathrm{~g} \mathrm{~L}^{-1}$ ethyl and methyl esters of fatty acids from Food Grade canola oil, used at 0.5 and $1.0 \%$; and

- Li-1000 ${ }^{\mathrm{TM}}$ (Etec Crop Solutions, New Zealand), a nonionic, lecithin + fatty acid esters + alcohol ethoxylate, Batch \# 230,285, used at 0.15 and $0.25 \%$.

All fungicide solutions were prepared according to label instructions using rates recommended by the Ministry for Primary Industries, New Zealand (MPI-NZ) (Table 1). Treatments were applied as $0.5 \mu$ d droplets delivered using a $25 \mu \mathrm{l}$ glass micro-syringe (Hamilton Company, Nevada, USA) fitted with a repeating dispenser (Hamilton Company, Nevada, USA). For each

Table 1 Fungicides (product and active ingredient) tested in the adjuvant selection trial

\begin{tabular}{llll}
\hline Product & Active ingredients (A.I.) & Distributor \& location & A.I. (\%w/v) \\
\hline Vandia ${ }^{\circledR}$ & Triademinol $250 \mathrm{~g} \mathrm{~L}^{-1}, \mathrm{EC}$ & Adria NZ & 0.05 \\
Saprol ${ }^{\circledR}$ & Triforine, $190 \mathrm{~g} \mathrm{~L}^{-1}, \mathrm{EC}$ & Orion NZ & 0.10 \\
Timorex Gold ${ }^{\circledR}$ & Natural extract of Melaleuca alternifolia, $225 \mathrm{~g} \mathrm{~L}^{-1}, \mathrm{EC}$ & Syngenta NZ & 0.40 \\
Radial ${ }^{\circledR}$ & Azoxystrobin + Epoxiconazole, $75+75 \mathrm{~g} \mathrm{~L}^{-1}, \mathrm{EC}$ & Adama NZ & 0.20 \\
Dedicate ${ }^{\circledR}$ & Tebuconazole + Trifloxystrobin, $200+100 \mathrm{~g} \mathrm{~L}^{-1}, \mathrm{SC}$ & Bayer Aust & 0.075 \\
Amistar Xtra ${ }^{\circledR}$ & Azoxystrobin + Cyproconazole, $200+80 \mathrm{~g} \mathrm{~L}^{-1}, \mathrm{SC}$ & Syngenta Aust & 0.10 \\
FirstUp ${ }^{\circledR}$ & Bio-fungicide XI 115A & BioPharm NZ & 0.50 \\
\hline
\end{tabular}


treatment, four separate droplets were placed on both abaxial and adaxial surfaces of single leaves (Fig. 1) from each of the three trees (i.e. 12 droplets per plant surface) to quantify spread. Each surface for adaxial and abaxial was tested separately. All treatments containing Actiwett ${ }^{\circledR}$ (alcohol ethoxylate) and Hasten ${ }^{\mathrm{TM}}$ (seed oil) included Blankophor P 167\% (Bayer AG, Leverkusen, Germany) fluorescent dye $(0.5 \% \mathrm{w} / \mathrm{v})$ for droplet visualisation under UV light. All treatments containing Li-1000 included Uvitex NFW 450\% (Huntsman) fluorescent dye $(0.5 \% \mathrm{w} / \mathrm{v})$. All tests were conducted at $20{ }^{\circ} \mathrm{C}$ and $\sim 55 \%$ relative humidity. Once droplets had dried, they were examined under UV light and photographed. Droplet spread images were processed in Adobe Photoshop CS3, and the droplet spread areas were quantified using $\mathrm{V}++$ image analysis software (Digital Optics, NZ).

\section{Determination of the efficacy of adjuvant-fungicide combinations against $A$. psidii}

\section{Plant materials for spray establishment trial and fungicide efficacy trial}

M. excelsa was used throughout this trial and were grown in $1.5 \mathrm{~L}$ pots as small shrubs that were approximately $0.80 \mathrm{~m}$ in height. Plants were grown in New Zealand Native Commercial Mix (Dalton ${ }^{\mathrm{TM}}$, New Zealand) supplemented with; DOLOMITE $2 \mathrm{~kg} \mathrm{~m}^{-3}$, GYPSUM COARSE $2 \mathrm{~kg} \mathrm{~m}^{-3}$,
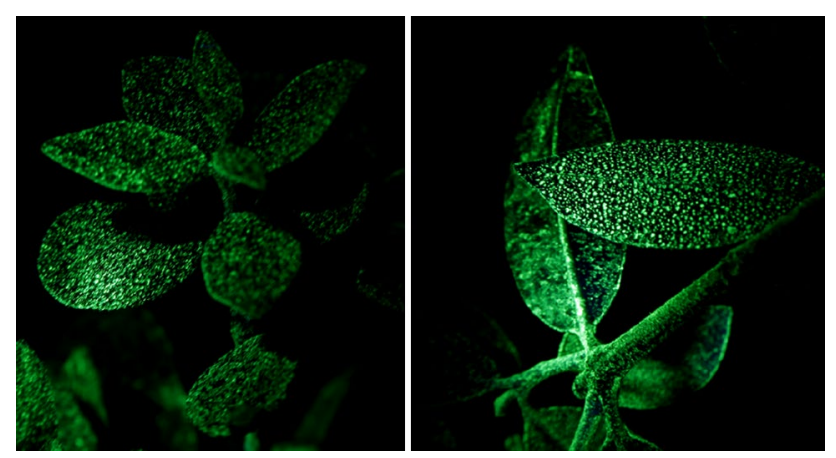

Fig. 2 Pictures of sprayed M. excelsa plants with Topline Paint (Topline Paint Pty LTD, Australia) showing the coverage achieved on the adaxial (left) and abaxial (right) leaf surfaces with spray application method used
LIME-AG GRADE $2 \mathrm{~kg} \mathrm{~m}^{-3}$, PERMAWET $0.75 \mathrm{~kg} \mathrm{M}^{-3}$,

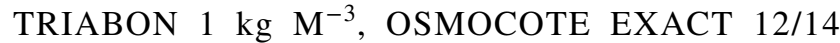
$6 \mathrm{~kg} \mathrm{M}^{-3}$, MICROPLUS (TE $\left.+\mathrm{Mg}+\mathrm{Fe}\right) 0.5 \mathrm{~kg} \mathrm{M}^{-3}$ and coconut fibre. The plants were kept at the Scion nursery (Rotorua, New Zealand) under shade from December 2018 to January 2019 until fungicide was applied.

\section{Spray application}

A preliminary experiment was undertaken to establish the rate as well as the method of fungicide application to produce optimum leaf coverage on $M$. excelsa plants. For all fungicide treatments, spray was released into an air-assisted (turbulent) environment created by three fans (GECDF300A 230-240 V $50 \mathrm{~Hz} 0.16 \mathrm{~A} 40 \mathrm{~W}$, GEC, China) that were evenly spaced around the tree at a $1 \mathrm{~m}$ radius from the target plant, at a height of $1 \mathrm{~m}$ above the ground and pointing towards the tree. The aim of this approach was to ensure the required dose was distributed over the entire plant, including abaxial and adaxial leaf surfaces (Fig. 2). A spinning disc atomiser (Micromiser 5, Micron Sprayers Ltd, Bromyard, UK) was positioned at $1 \mathrm{~m}$ directly above the target plant. The spinning disc atomiser was set up to deliver spray at a rate of $300 \mathrm{~mL} \mathrm{~min}^{-1}$ with a disc speed of $\sim 6250 \mathrm{rpm}$. Under these conditions a droplet spectrum was produced with a volume median diameter (VMD) of $130 \mu \mathrm{m}$. The droplet spectrum was confirmed by measuring crater diameters and applying the appropriate spread factor from samples of droplets caught on microscope slides coated with magnesium oxide (May 1950). Measurements of spray deposition using standard methods (May 1950) indicated that spraying for $40 \mathrm{~s}$ delivered the required rate of $1500 \mathrm{~L} / \mathrm{ha}$ to the target plates where the treatment plant was located. For all trials, the room temperature remained between 18 and $25^{\circ} \mathrm{C}$ with a relative humidity $(\mathrm{RH})$ of $85 \%$.

\section{Fungicide-adjuvant efficacy test}

Three fungicides (Table 2) were applied to $M$. excelsa plants with $0.75 \%$ alcohol ethoxylate adjuvant based on results from the study described in the adjuvant selection trials section. Applications were made in a total spray volume of $1500 \mathrm{~L} \mathrm{ha}^{-1}$ as described in the spray application section. The fungicides used for this study were selected either because their mode of action is known to be effective
Table 2 Fungicides and Adjuvant (Actiwett) rate(s) used for trial

\begin{tabular}{llll}
\hline Active ingredients (A.I.) & $\begin{array}{l}\text { A.I. Rates (ml } \\
\left.\mathrm{L}^{-1}\right)\end{array}$ & $\begin{array}{l}\text { Actiwett (ml } \\
\left.\mathrm{L}^{-1}\right)\end{array}$ & A.I ( $\left.\mathrm{La}^{-1}\right)$ \\
\hline Tea tree oil (natural extract of Melaleuca alternifolia) & 2.0 & 0.75 & 1.5 \\
Triadimenol +(1-Methyl 2-pyrrollidinon) & 1.12 & 0.75 & 0.84 \\
Azoxystrobin +Epoxiconazole & 0.84 & 0.75 & 1.49 \\
\hline
\end{tabular}


(strobilurins and triazoles) or because they are natural product extracts with the potential to be more environmentally acceptable. Each fungicide and adjuvant mix were applied separately to 32 plants except for the untreated control plants. The plants were sprayed with fungicides on the same day and inoculated at intervals of $0,7,14$ or 21 days (Supplementary table 1), post-spraying. Untreated controls were also inoculated at the same intervals. Post-treatment, all plants were kept in the shade house and watered via drip irrigation pipes placed directly into the pot until they were taken to the containment facility where they were inoculated with A. psidii as described in next section.

\section{Spore collection and development of inoculation procedures}

Following spraying, plants were divided into four groups and each group was inoculated with $A$. psidii at either $0,7,14$ or 21 days (Supplementary table 1 ) after spraying. To ensure containment of rust spores, in accordance with regulatory requirements in place at that time, all experimental work was performed in a PC1 facility. Austropuccinia psidii urediniospores (spores) were collected from naturally infected Lophomyrtus bullata (ramarama) plants in the field with the use of a portable vacuum pump (Mini Cyclone Spore Collector GRA-201) device powered by a $12 \mathrm{~V}$ battery into capsules ( 00 gelatin caps). The capsules ( 00 gelatin caps) were opened and kept in silica jar for $48 \mathrm{~h}$ for air-drying. The air-dried spores in the capsules ( 00 gelatin caps) were covered and transferred into $-80^{\circ} \mathrm{C}$ freezer. Prior to inoculation, stored spores were removed from $-80^{\circ} \mathrm{C}$ and allowed to warm to room temperature. The viability of the spores was assessed following the Tesmann and Dianese (2002) protocol. The concentration of the spores for inoculation was assessed by suspending spores in $0.01 \%$ Tween 20 (Sigma ${ }^{\circledR}$ ) and counted with hemocytometer. Spore concentration was adjusted to $4 \times 10^{6}$ spores $\mathrm{ml}^{-1}$ and droplets of inoculum were applied to adaxial and abaxial leaf surfaces of the $M$. excelsa test plants using a manually operated hand sprayer (30 $\mathrm{mL}$ spray bottle).

Inoculated plants were kept in darkness in a humidity chamber RH (80--99\%) at $18-23{ }^{\circ} \mathrm{C}$ for $26 \mathrm{~h}$. At $26 \mathrm{~h}$, the inoculated plants were taken out of the humidity chamber and moved into a controlled environment in the presence of light. Temperature and relative humidity were recorded. An irrigation system delivered water directly into the pots of treatment plants so as not to wash off inoculated spores and fungicides from the foliage. For similar reasons, the floor of the controlled rooms was flooded throughout the study without a misting system to maintain RH at 80-90\% Post-inoculation assessment, involving qualitative scoring of disease symptoms (see below), was conducted at 21, 28 or 35 days after inoculation.

\section{Assessment of disease/infections}

Prior to treating the M. excelsa plants with fungicides, the total number of young shoots on each plant and their health conditions were visually assessed and recorded (not shown) to select vital plants. Following the treatment application, plants were re-assessed at 21,28 or 35 days post-inoculation and the total number of infected shoots recorded. The total number of young leaf pairs, and infected leaves was counted, and an overall disease rating conducted for the leaves and nodal parts of the three most infected shoots on each plant. The most infected leaf of each leaf-pair on the selected shoots was labelled and its adaxial and abaxial surfaces were independently scored throughout the study. The disease rating scales used for scoring leaves and nodal parts were based on Junghans et al. (2003): $1=$ no symptoms evident or presence of yellow flecking; $2=$ presence of a hypersensitive reaction (HR) with fleck or necrosis; $3=$ small pustules, $<0.8 \mathrm{~mm}$ diameter, with one or two uredinia; $4=$ medium-sized pustules, $0.8-1.6 \mathrm{~mm}$ diameter with about 12 uredinia; $5=$ large pustules, $>1.6 \mathrm{~mm}$ diameter, with 20 or more uredinia on leaves, petioles and/or shoots. In this current study we also added a new disease rating scale: $6=$ dieback (i.e. dead leaf resulting from infection).

\section{Statistical analysis}

The adjuvant trial treatments comprised combinations of seven fungicides applied alone as controls or with each of the 3 adjuvants at two rates. Analysis of variance was performed on spread area data for the adjuvant treatments using Statistix 10 (Analytical Software, USA) and mean values were compared using LSD.

The fungicide-adjuvant efficacy trial was designed as a $4 \times 4$ factorial ( 3 fungicide treatments, control treatment and 4 inoculation times) arranged in a split plot design with eight replications. Inoculation timing was set as the whole plot factor with fungicide (including control plants) set as the sub-plot factor.

\section{Leaf and nodal disease scores}

Given the more complex nature of the disease scoring data, the leaf and nodal disease scores were analysed using cumulative link mixed models (CLMM) with logit link fitted by Laplace approximation (R package ordinal, Christensen 2019). Inoculation time $(0,7,14$ or 21 days after fungicide application), fungicide treatment (Control + Adjuvant, Azoxystrobin/Epoxiconazole + Adjuvant, Natural extract of Melaleuca alternifolia + Adjuvant, Triademinol + Adjuvant), leaf surface (adaxial, abaxial) and their interactions formed the fixed effects term of the model. The random term reflected the multilevel study design with the following 
nesting structure from the highest to the lowest level for the leaf disease model: Block/inoculation time/fungicide treatment/leaf surface/plant/shoot number. The random term of the nodal disease model had the following structure: block/ inoculation time/fungicide treatment/plant. The overwhelming majority of the foliage remained symptom-free over time (82.3\% of all observations) and therefore the analysis was restricted to diseased leaves. Due to model convergence issues (overparameterisation), separate CLMMs were run for the three assessment dates $(21,28$ and 35 days after inoculation). A comparison of models with identical fixed and random terms but different threshold options (flexible, equidistant, two varieties of symmetric thresholds) based on the Akaike Information Criterion (AIC) indicated that flexible thresholds were best suited for the leaf disease score data $(\triangle \mathrm{AIC}>10$ in favour of the CLMM with flexible thresholds). For the nodal disease score data CLMMs showed minor differences between flexible, equidistant and symmetric thresholds $(\Delta \mathrm{AIC}<3)$ and we therefore opted for the default flexible thresholds.

\section{Percentage leaf and shoot infection}

Since the raw data underlying the percentages of infected leaves and shoots were available, we applied a generalised linear mixed effects model (GLMM) with binomial errors and logit link using maximum likelihood estimation (R package glmmTMB, Brooks et al. 2017). The binomial response was specified by a two-column matrix holding the number of infected leaves (or shoots) and the number of uninfected leaves (or shoots). The fixed term of the model comprised inoculation time, fungicide treatment, assessment date and their interactions. The random term of the leaf GLMM consisted of the following top-down nesting structure: block/ inoculation time/fungicide treatment/plant. Since there was no sub-replication beyond the shoot level, the random term of the GLMM applied to the shoot data only consisted of the nested term: block/inoculation time/fungicide treatment. The observations associated with inoculation time T14 were omitted from the analysis because infection scores at T14 were not different from T7.

For all models, the significance of the explanatory variables was assessed using a backwards selection approach based on likelihood ratio tests. Statistically significant effects were followed up with a post-hoc analysis using the Benjamini and Hochberg (1995) multiplicity adjustment (R package emmeans 1.4.4) (Lenth 2020; Lenth et al. 2020).

\section{Results}

\section{Determination of droplet spread for adjuvant-fungicide combinations}

\section{Adjuvant selection}

Mean droplet spread areas over all treatments for adaxial or abaxial leaf surfaces and for plants 1 or 3 were $5.11 \mathrm{~mm}^{2}$ and $4.85 \mathrm{~mm}^{2}$, respectively, with no significant differences $(P<0.05)$ between them (data not presented). Plant 2 was visibly different, and treatment spread was significantly different $(P<0.0001)$ to both plants 1 and 3 on both surfaces of $M$. excelsa leaves (i.e. abaxial or adaxial). The overall mean value for spread area on plant 2 (Fig. 1) was $6.37 \mathrm{~mm}^{2}$, with no significant differences $(P<0.05)$ for spread on adaxial or abaxial leaf surfaces.

Triforine, Bio-fungicide XI 115A and the natural extract of Melaleuca alternifolia spread well on adaxial leaf surfaces, and triforine and Bio-fungicide XI 115A spread very well on abaxial surfaces (Table 3 ). On abaxial leaf surfaces, the Bio-fungicide XI 115A spray did not spread well, even when adjuvant was added (Table 3), whereas all adjuvants consistently improved spreading of azoxystrobin + epoxiconazole, tebuconazole + trifloxystrobin and azoxystrobin + cyproconazole (Table 3 ).

The alcohol ethoxylate consistently improved spreading of all sprays on at least one leaf surface and often on both (Table 3). Generally, increasing concentration of the alcohol ethoxylate increased spreading. Overall, there were no significant differences $(P<0.05)$ between the seed oil, Hasten ${ }^{\mathrm{TM}}$, and lecithin, Li-1000 ${ }^{\mathrm{TM}}$ and their concentrations had little effect on spreading (Table 3). Generally, the seed oil and lecithin improved spreading more on the more difficult-to-wet abaxial leaf surface (Table 3), but never as much as the alcohol ethoxylate. Hence, the alcohol ethoxylate was selected as the adjuvant for the fungicide mix in this study, to maximise spray coverage on leaves.

\section{Fungicide treatment efficacy}

\section{Leaf infection scores}

Following spraying, and inoculation, infection with $A$. psidii and subsequent sporulation was observed on whole M. excelsa plants, shoots and adaxial (Fig. 3a) and abaxial (Fig. 3b) leaf surfaces, as well as shoot internodes (Fig. 3c). Three weeks after inoculation, infected leaves in both treated and control $M$. excelsa plants showed dieback (Fig. 3d). 
Table 3 Spread areas of fungicide \pm adjuvant treatments on the Adaxial and Abaxial leaf surfaces of $M$. excelsa

\begin{tabular}{|c|c|c|c|}
\hline \multicolumn{2}{|l|}{ Fungicides $\&$ adjuvants concentrations } & \multicolumn{2}{|c|}{$\begin{array}{l}\text { Mean }( \pm \text { SD }) \text { spread areas on lea } \\
\text { surface }\left(\mathrm{mm}^{2}\right)\end{array}$} \\
\hline Fungicide (concentration\%) & Adjuvant (concentration \%) & Adaxial & Abaxial \\
\hline \multirow[t]{7}{*}{ Triadimenol $(0.05)^{\mathrm{b}}$} & Nil (-) & $3.85 \pm 1.42$ & $3.13 \pm 0.41$ \\
\hline & Actiwett $(0.05)$ & $5.64 \pm 0.70^{\mathrm{a}}$ & $10.95 \pm 4.43^{\mathrm{a}}$ \\
\hline & Actiwett (0.075) & $7.93 \pm 3.59^{\mathrm{a}}$ & $12.72 \pm 4.25^{\mathrm{a}}$ \\
\hline & Hasten (0.5) & $3.97 \pm 0.57^{\mathrm{a}}$ & $5.05 \pm 0.44^{\mathrm{a}}$ \\
\hline & Hasten (1.0) & $4.47 \pm 1.43^{\mathrm{a}}$ & $5.39 \pm 0.43^{\mathrm{a}}$ \\
\hline & $\mathrm{Li}-1000(0.15)$ & $3.54 \pm 0.57$ & $5.48 \pm 0.57^{\mathrm{a}}$ \\
\hline & Li-1000 (0.25) & $3.59 \pm 1.16$ & $5.87 \pm 1.36^{\mathrm{a}}$ \\
\hline \multirow[t]{7}{*}{ Triforine $(0.10)$} & Nil (-) & $5.89 \pm 2.42$ & $7.21 \pm 0.76^{\mathrm{a}}$ \\
\hline & Actiwett (0.05) & $6.03 \pm 0.70^{\mathrm{a}}$ & $11.01 \pm 2.99^{\mathrm{a}}$ \\
\hline & Actiwett (0.075) & $7.98 \pm 4.76^{\mathrm{a}}$ & $9.18 \pm 0.54^{\mathrm{a}}$ \\
\hline & Hasten (0.5) & $4.30 \pm 0.49^{\mathrm{a}}$ & $5.68 \pm 0.58$ \\
\hline & Hasten (1.0) & $4.66 \pm 0.75^{\mathrm{a}}$ & $5.15 \pm 0.26$ \\
\hline & Li-1000 (0.15) & $3.60 \pm 0.27$ & $5.62 \pm 1.05$ \\
\hline & Li-1000 (0.25) & $3.68 \pm 0.55$ & $5.80 \pm 0.97$ \\
\hline \multirow[t]{7}{*}{ Extract of Melaleuca alternifolia $(0.40)^{\mathrm{b}}$} & Nil (-) & $4.66 \pm 1.54$ & $3.81 \pm 0.65$ \\
\hline & Actiwett $(0.05)$ & $3.95 \pm 0.39$ & $8.41 \pm 4.31^{\mathrm{a}}$ \\
\hline & Actiwett (0.075) & $5.54 \pm 1.36^{\mathrm{a}}$ & $6.41 \pm 0.46^{\mathrm{a}}$ \\
\hline & Hasten (0.5) & $3.61 \pm 0.45$ & $6.29 \pm 2.77^{\mathrm{a}}$ \\
\hline & Hasten (1.0) & $4.73 \pm 0.84^{\mathrm{a}}$ & $4.73 \pm 0.36^{\mathrm{a}}$ \\
\hline & $\mathrm{Li}-1000(0.15)$ & $4.40 \pm 0.66$ & $5.34 \pm 0.84^{\mathrm{a}}$ \\
\hline & Li-1000 (0.25) & $3.64 \pm 0.86$ & $6.16 \pm 1.43^{\mathrm{a}}$ \\
\hline \multirow[t]{7}{*}{ Azoxystrobin + Epoxiconazole $(0.20)$} & Nil (-) & $3.00 \pm 0.59$ & $2.25 \pm 0.41$ \\
\hline & Actiwett (0.05) & $5.35 \pm 0.71$ & $10.54 \pm 3.87$ \\
\hline & Actiwett (0.075) & $6.05 \pm 1.27$ & $12.41 \pm 4.52$ \\
\hline & Hasten $(0.5)$ & $3.62 \pm 0.74$ & $5.82 \pm 2.86$ \\
\hline & Hasten (1.0) & $4.25 \pm 1.14$ & $4.54 \pm 0.49$ \\
\hline & Li-1000 (0.15) & $4.03 \pm 0.36$ & $4.65 \pm 0.44$ \\
\hline & $\mathrm{Li}-1000(0.25)$ & $4.24 \pm 1.38$ & $6.08 \pm 1.65$ \\
\hline \multirow[t]{7}{*}{ Tebuconazole + Trifloxystrobin (0.075) } & Nil (-) & $2.54 \pm 0.37$ & $1.55 \pm 0.53$ \\
\hline & Actiwett $(0.05)$ & $6.49 \pm 3.34^{\mathrm{a}}$ & $8.70 \pm 3.92^{\mathrm{a}}$ \\
\hline & Actiwett (0.075) & $6.92 \pm 1.44^{\mathrm{a}}$ & $11.89 \pm 3.88^{\mathrm{a}}$ \\
\hline & Hasten $(0.5)$ & $3.93 \pm 0.42^{\mathrm{a}}$ & $4.46 \pm 0.59^{\mathrm{a}}$ \\
\hline & Hasten (1.0) & $4.69 \pm 1.60^{\mathrm{a}}$ & $5.01 \pm 0.71^{\mathrm{a}}$ \\
\hline & Li-1000 (0.15) & $3.25 \pm 0.32^{\mathrm{a}}$ & $5.07 \pm 0.82^{\mathrm{a}}$ \\
\hline & Li-1000 (0.25) & $3.62 \pm 1.03^{\mathrm{a}}$ & $5.41 \pm 1.49^{\mathrm{a}}$ \\
\hline \multirow[t]{7}{*}{ Azoxystrobin + Cyproconazole $(0.10)^{\mathrm{b}}$} & Nil (-) & $2.37 \pm 0.23$ & $2.17 \pm 0.64$ \\
\hline & Actiwett $(0.05)$ & $5.47 \pm 1.54^{\mathrm{a}}$ & $8.66 \pm 3.72^{\mathrm{a}}$ \\
\hline & Actiwett (0.075) & $6.10 \pm 1.38^{\mathrm{a}}$ & $8.35 \pm 1.34^{\mathrm{a}}$ \\
\hline & Hasten (0.5) & $3.05 \pm 0.28^{\mathrm{a}}$ & $3.96 \pm 0.24^{\mathrm{a}}$ \\
\hline & Hasten (1.0) & $4.36 \pm 0.66^{\mathrm{a}}$ & $4.42 \pm 0.48^{\mathrm{a}}$ \\
\hline & Li-1000 (0.15) & $3.01 \pm 0.24^{\mathrm{a}}$ & $5.40 \pm 1.10^{\mathrm{a}}$ \\
\hline & $\mathrm{Li}-1000(0.25)$ & $3.08 \pm 0.51^{\mathrm{a}}$ & $4.25 \pm 0.71^{\mathrm{a}}$ \\
\hline \multirow[t]{7}{*}{ Bio-fungicide XI 115A (0.5) } & Nil (-) & $4.58 \pm 0.51$ & $8.96 \pm 1.18$ \\
\hline & Actiwett (0.05) & $4.39 \pm 1.21$ & $10.72 \pm 2.56^{\mathrm{a}}$ \\
\hline & Actiwett (0.075) & $4.53 \pm 0.67$ & $8.14 \pm 0.68$ \\
\hline & Hasten (0.5) & $3.87 \pm 1.58$ & $6.16 \pm 0.89$ \\
\hline & Hasten (1.0) & $4.18 \pm 1.08$ & $5.48 \pm 0.35$ \\
\hline & Li-1000 (0.15) & $3.77 \pm 1.22$ & $6.63 \pm 1.62$ \\
\hline & Li-1000 (0.25) & $3.53 \pm 0.32$ & $5.79 \pm 0.40$ \\
\hline
\end{tabular}

${ }^{a}$ Values are significantly higher than nil-adjuvant fungicide control

${ }^{\mathrm{b}}$ Three fungicides (Triadimenol, Natural extract of Melaleuca alternifolia and Azoxystrobin + Epoxiconazole) were used for subsequent fungicide efficacy trials due to limited space in containment facility 
Fig. 3 Austropuccinia psidii urediniospores infecting a adaxial leaf surfaces, $\mathbf{b}$ abaxial leaf surfaces, $\mathbf{c}$ internodes and causing $\mathbf{d}$ dieback on leaves
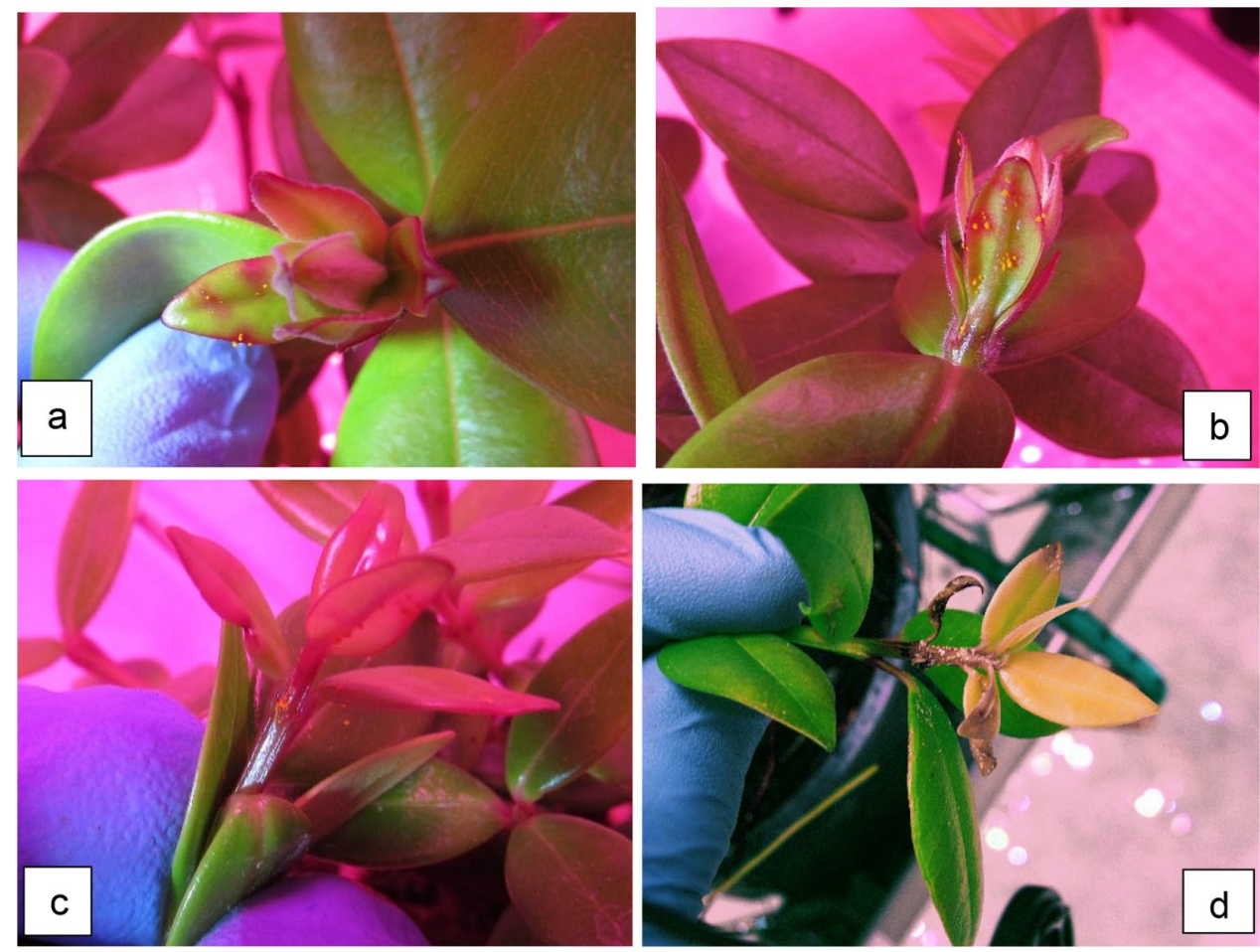

For the treatment where inoculation took place seven days (i.e. T7) after fungicide application, the inoculation time $x$ fungicide treatment interaction was statistically significant at the first assessment date (21 days after inoculation) (Table 4). A post-hoc analysis revealed that the interaction was driven by more pronounced disease symptoms in the control and the triademinol-treated plants compared to the plants treated with the natural extract of Melaleuca alternifolia and the azoxystrobin + epoxiconazole mix (Table 5 and Fig. 4, see T7 in the top panel). This two-way interaction was not significant at the 28 days $(\mathrm{P}=0.055)$ and 35 days $(P=0.052)$ assessments, possibly reflecting the lower infection levels for the inoculation carried out shortly after application (T0). None of the remaining two-way interactions were statistically significant at any of the following assessments. At all assessment dates, disease symptoms were significantly worse on the abaxial compared to the adaxial leaf surface (Fig. 4 and Table 4), despite good coverage of fungicides on both leaf surfaces. The three-way interactions between inoculation time, fungicide treatment and leaf side were not statistically significant, irrespective of assessment date (Table 4).

\section{Percentage leaf infection}

None of the interaction terms nor the main effects of inoculation time or assessment date produced statistically significant effects (Table 6). A significant fungicide main effect was driven by consistently lower probabilities of infected leaves associated with azoxystrobin + epoxiconazole at T0, T7 and T21, (Fig. 5 and Table 6) for all assessment days. The probabilities of infected leaves related to the remaining two fungicides neither differed from the control nor from each other (Fig. 5 and Table 7).

\section{Percentage shoot infection}

Neither the inoculation time $\mathrm{x}$ fungicide $\mathrm{x}$ assessment date interaction nor any of the three two-way interactions was statistically significant (Table 8). The predicted proportion of infected shoots was generally somewhat higher in the control group compared to the fungicide-treated plants, which resulted in a significant fungicide treatment main effect (Table 8). A post-hoc analysis showed that these differences were only statistically significant between the control plants and those treated with the azoxystrobin + epoxiconazole (Fig. 6). The assessment date did not have a significant effect, but the inoculation times differed significantly from each other (Fig. 6 and Table 8). In this study, a post-hoc comparison revealed that inoculation time T0 had significantly lower probabilities of infected shoots compared to inoculation time $\mathrm{T} 7$ and $\mathrm{T} 21$, which produced similar shoot infection probabilities (Fig. 6 and Table 9). 
Table 4 Likelihood ratio test results from a backwards selection procedure applied to a cumulative link mixed effects model (CLMM) testing the effects of inoculation time, fungicide treatment, leaf side and their interactions on the leaf disease rating at three assessment dates post-inoculation

\begin{tabular}{llll}
\hline Dropped term & $L$ & $d f$ & $P$ \\
\hline
\end{tabular}

\begin{tabular}{|c|c|c|c|}
\hline \multicolumn{4}{|l|}{21 days after inoculation } \\
\hline \multicolumn{4}{|l|}{ First stage } \\
\hline $\begin{array}{l}\text { Inoculation time } \times \text { Fungi- } \\
\text { cide } \times \text { Leaf side }\end{array}$ & 6.35 & 9 & 0.705 \\
\hline \multicolumn{4}{|l|}{ Second stage } \\
\hline $\begin{array}{l}\text { Inoculation time } \times \text { Fun- } \\
\text { gicide }\end{array}$ & 19.75 & 9 & $0.020 *$ \\
\hline $\begin{array}{l}\text { Inoculation time } \times \text { Leaf } \\
\text { side }\end{array}$ & 3.38 & 3 & 0.337 \\
\hline Fungicide $\times$ Leaf side & 3.71 & 3 & 0.294 \\
\hline \multicolumn{4}{|l|}{ Third stage } \\
\hline Leaf side & 46.69 & 1 & $<0.001 * * *$ \\
\hline \multicolumn{4}{|l|}{28 days after inoculation } \\
\hline \multicolumn{4}{|l|}{ First stage } \\
\hline $\begin{array}{l}\text { Inoculation time } \times \text { Fungi- } \\
\text { cide } \times \text { Leaf side }\end{array}$ & 4.73 & 9 & 0.857 \\
\hline \multicolumn{4}{|l|}{ Second stage } \\
\hline $\begin{array}{l}\text { Inoculation time } \times \text { Fun- } \\
\text { gicide }\end{array}$ & 16.61 & 9 & 0.055 \\
\hline $\begin{array}{l}\text { Inoculation time } \times \text { Leaf } \\
\text { side }\end{array}$ & 1.16 & 3 & 0.762 \\
\hline Fungicide $\times$ Leaf side & 1.43 & 3 & 0.697 \\
\hline \multicolumn{4}{|l|}{ Third stage } \\
\hline Inoculation time & 4.37 & 3 & 0.224 \\
\hline Fungicide & 5.96 & 3 & 0.114 \\
\hline Leaf side & 39.07 & 1 & $<0.001 * * *$ \\
\hline \multicolumn{4}{|l|}{35 days after inoculation } \\
\hline \multicolumn{4}{|l|}{ First stage } \\
\hline $\begin{array}{l}\text { Inoculation time } \times \text { Fungi- } \\
\text { cide } \times \text { Leaf side }\end{array}$ & 4.38 & 9 & 0.885 \\
\hline \multicolumn{4}{|l|}{ Second stage } \\
\hline $\begin{array}{l}\text { Inoculation time } \times \text { Fun- } \\
\text { gicide }\end{array}$ & 16.80 & 9 & 0.052 \\
\hline $\begin{array}{l}\text { Inoculation time } \times \text { Leaf } \\
\text { side }\end{array}$ & 0.70 & 3 & 0.873 \\
\hline Fungicide $\times$ Leaf side & 2.93 & 3 & 0.402 \\
\hline \multicolumn{4}{|l|}{ Third stage } \\
\hline Inoculation time & 5.82 & 3 & 0.121 \\
\hline Fungicide & 4.81 & 3 & 0.187 \\
\hline Leaf side & 21.45 & 1 & $<0.001^{* * *}$ \\
\hline
\end{tabular}

${ }^{\mathrm{a}} \mathrm{L}=$ likelihood ratio statistic, ${ }^{\mathrm{b}} \mathrm{df}=$ degrees of freedom of the $\mathrm{L}$ statistic, ${ }^{\mathrm{c}} \mathrm{P}=\mathrm{P}$-value. ${ }^{*} \mathrm{P}<0.05, * * \mathrm{P}<0.01, * * * \mathrm{P}<0.001$

\section{Discussion}

An artificial inoculation assay was developed for myrtle rust under controlled conditions for the first time in New Zealand
Table 5 Results from a post-hoc analysis contrasting the fungicide treatments within inoculation times associated with the CLMM for the assessment 21 days post-inoculation (slicing the significant inoculation time $\times$ fungicide interaction)

\begin{tabular}{|c|c|c|c|c|}
\hline Contrast & Estimate & SE & $\mathrm{z}$ & Padj \\
\hline \multicolumn{5}{|c|}{ Inoculation time TO } \\
\hline $\mathrm{C}-\mathrm{R}$ & 0.70 & 1.06 & 0.66 & 0.761 \\
\hline $\mathrm{C}-\mathrm{T}$ & -0.07 & 0.63 & -0.12 & 0.906 \\
\hline $\mathrm{C}-\mathrm{V}$ & 0.93 & 0.74 & 1.26 & 0.621 \\
\hline $\mathrm{R}-\mathrm{T}$ & -0.77 & 1.06 & -0.73 & 0.761 \\
\hline $\mathrm{R}-\mathrm{V}$ & 0.23 & 1.14 & 0.20 & 0.906 \\
\hline $\mathrm{T}-\mathrm{V}$ & 1.01 & 0.78 & 1.29 & 0.621 \\
\hline \multicolumn{5}{|c|}{ Inoculation time $T 7$} \\
\hline $\mathrm{C}-\mathrm{R}$ & 2.36 & 0.61 & 3.85 & $<0.001 * * *$ \\
\hline $\mathrm{C}-\mathrm{T}$ & 2.44 & 0.59 & 4.14 & $<0.001 * * *$ \\
\hline $\mathrm{C}-\mathrm{V}$ & 0.62 & 0.60 & 1.04 & 0.358 \\
\hline $\mathrm{R}-\mathrm{T}$ & 0.08 & 0.58 & 0.14 & 0.892 \\
\hline $\mathrm{R}-\mathrm{V}$ & -1.73 & 0.67 & -2.58 & $0.015^{*}$ \\
\hline $\mathrm{T}-\mathrm{V}$ & -1.82 & 0.62 & -2.93 & $0.007 * *$ \\
\hline \multicolumn{5}{|c|}{ Inoculation time T14 } \\
\hline $\mathrm{C}-\mathrm{R}$ & -0.38 & 0.72 & -0.53 & 0.898 \\
\hline $\mathrm{C}-\mathrm{T}$ & -0.32 & 1.39 & -0.23 & 0.966 \\
\hline $\mathrm{C}-\mathrm{V}$ & 0.73 & 0.79 & 0.92 & 0.824 \\
\hline $\mathrm{R}-\mathrm{T}$ & 0.06 & 1.47 & 0.04 & 0.966 \\
\hline $\mathrm{R}-\mathrm{V}$ & 1.11 & 0.93 & 1.20 & 0.824 \\
\hline $\mathrm{T}-\mathrm{V}$ & 1.05 & 1.28 & 0.82 & 0.824 \\
\hline \multicolumn{5}{|c|}{ Inoculation time $T 21$} \\
\hline $\mathrm{C}-\mathrm{R}$ & -0.85 & 0.76 & -1.12 & 0.692 \\
\hline $\mathrm{C}-\mathrm{T}$ & -0.13 & 0.60 & -0.23 & 0.822 \\
\hline $\mathrm{C}-\mathrm{V}$ & 0.14 & 0.53 & 0.27 & 0.822 \\
\hline $\mathrm{R}-\mathrm{T}$ & 0.71 & 0.76 & 0.94 & 0.692 \\
\hline $\mathrm{R}-\mathrm{V}$ & 0.99 & 0.74 & 1.33 & 0.692 \\
\hline$T-V$ & 0.27 & 0.62 & 0.44 & 0.822 \\
\hline
\end{tabular}

${ }^{\mathrm{a}}$ Estimate Estimated difference, ${ }^{\mathrm{b}} S E$ Standard error of the difference, ${ }^{\mathrm{c}} \mathrm{z}$ z-value (infinite degrees of freedom), ${ }^{\mathrm{d}}$ Padj Multiplicity adjusted $P$ value (Banjamini and Hochberg method 1995)

in this study. The artificial inoculation method was applied in M. excelsa plants for fungicide preventative trials to study the efficacy of three fungicides supplemented with adjuvant. In this study, a spray application technique that operated on air-assisted spray application was developed to enhance fungicide deposition and coverage of leaf surfaces.

In the current study, inoculation assay was successfully established and differed from inoculation procedures as well as incubation conditions such as temperature, humidity and light described by Morin et al. (2012) and Pathan et al. (2020). The use of adjuvants has been shown to be very important in the application of fungicides because of their ability to improve fungicide persistence, retention, spread, coverage, penetration and efficacy when applied to surfaces of plants (Percich and Nickelson 1982; Steurbaut 
Fig. 4 Predicted probabilities from a cumulative link mixed effects model for the leaf disease rating on the adaxial (upper) and abaxial (lower) leaf surface at 21,28 and 35 days after inoculation (top, middle and bottom panels, respectively). $\mathrm{T} 0=$ inoculation of M. excelsa plants with Austropuccinia psidii at the same day of the fungicide application, T7, T14 and T21 = inoculation at 7, 14 and 21 days after fungicide application. Fungicide (a.i.) = Vandia (triademinol), Timorex Gold (Natural extract of Melaleuca alternifolia), Radial (azoxystrobin + epoxiconazole). Fungicide treatments: $\mathrm{C}=\mathrm{Con}-$ trol, $\mathrm{R}=$ Radial + Adjuvant, $\mathrm{T}=$ Timorex Gold + Adjuvant, $\mathrm{V}=$ Vandia + Adjuvant
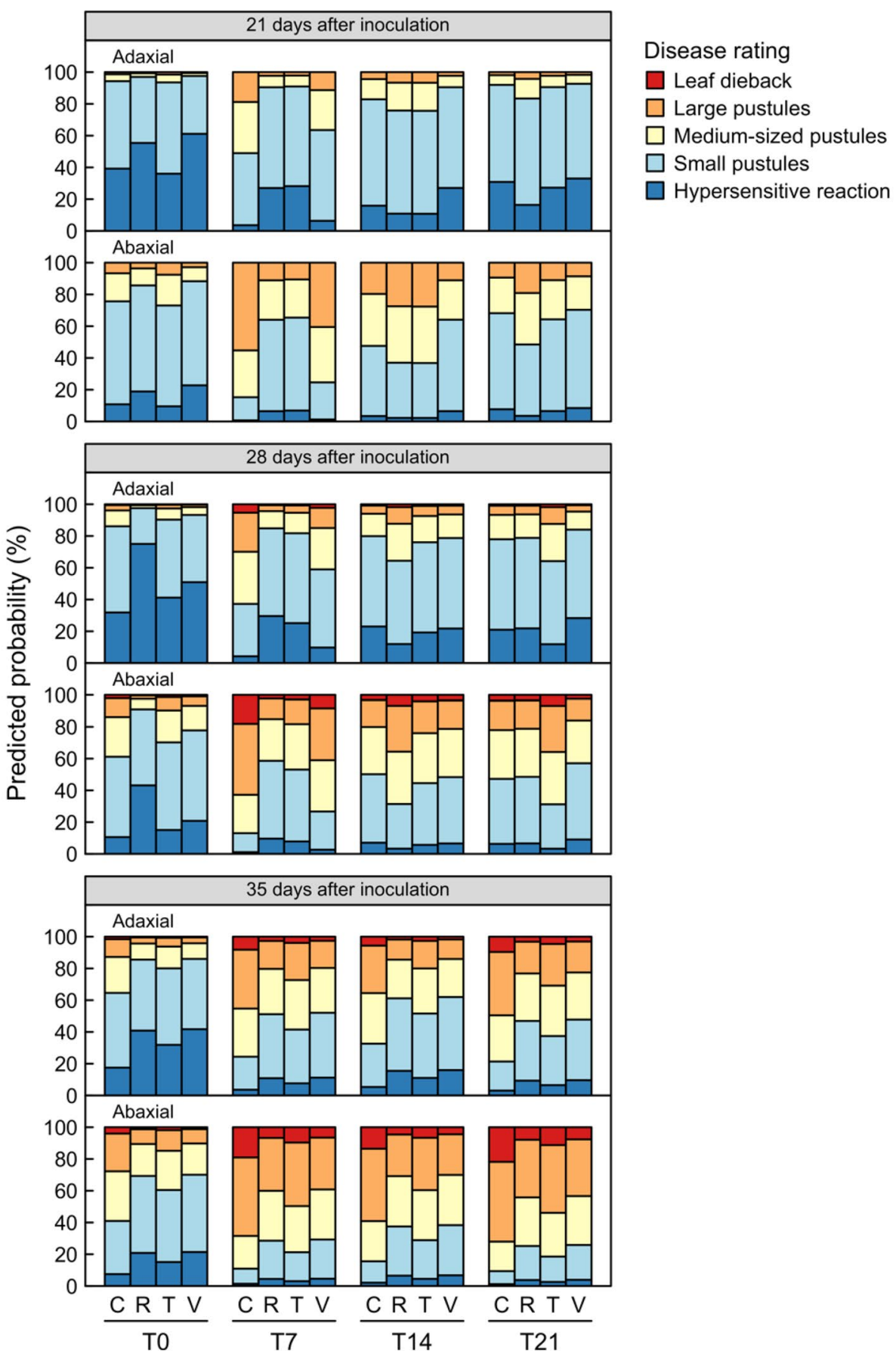

1993; Thompson et al. 1996; Gent et al. 2003). Adjuvants have also been reported to correct $\mathrm{pH}$, drifting and foaming of tank water (Bakke 2007). Research publications on field applications using fungicide mixed with adjuvants are rare (Foy 1993; Steurbaut 1993; Gent et al. 2003). The spread of the three adjuvants mixed with fungicides varied on both the adaxial and abaxial leaf surfaces. However, the alcohol ethoxylate was shown to be particularly effective. The presence of hair cuticles in $M$. excelsa leaves most likely affected the spread and coverage of fungicide mixed with the three adjuvants used in this study. Hence, the variation in the spread of the fungicide combined with adjuvants on the adaxial and abaxial M. excelsa leaf surfaces observed. This outcome highlights the inherent variability in leaf surface characteristics within a species and the impacts this can have on fungicide spreading, and ultimately performance. There was a range of spreading exhibited by the seven fungicide formulations; some obviously included more surface-active components (adjuvants) in their formulation than others. Plant leaves with features such as waxy cuticles have been 
Table 6 Likelihood ratio test results from a backwards selection procedure applied to a generalised linear mixed effect model (GLMM) testing the effects of inoculation time, fungicide treatment, assessment date and their interactions on the proportion of infected leaves

\begin{tabular}{llll}
\hline Dropped term & $\mathrm{L}$ & $\mathrm{df}$ & $\mathrm{P}$ \\
\hline $\begin{array}{l}\text { First stage } \\
\begin{array}{l}\text { Inoculation time } \times \text { Fungicide } \times \text { Assess- } \\
\text { ment date }\end{array}\end{array}$ & 0.20 & 12 & 1 \\
$\begin{array}{l}\text { Second stage } \\
\text { Inoculation time } \times \text { Fungicide }\end{array}$ & 5.70 & 6 & 0.458 \\
Inoculation time $\times$ assessment date & 0.18 & 4 & 0.996 \\
$\begin{array}{l}\text { Fungicide } \times \text { Assessment date } \\
\text { Third stage }\end{array}$ & 0.10 & 6 & 1 \\
Inoculation time & & & \\
Fungicide & 3.87 & 2 & 0.145 \\
Assessment date & 7.93 & 3 & $0.048^{*}$ \\
\hline
\end{tabular}

${ }^{\mathrm{a}} \mathrm{L}$ Likelihood ratio statistic, ${ }^{\mathrm{b}} \mathrm{df}$ Degrees of freedom of the $\mathrm{L}$ statistic, ${ }^{\mathrm{c}} \mathrm{P} \mathrm{P}$ value. $* \mathrm{P}<0.05, * * \mathrm{P}<0.01, * * * \mathrm{P}<0.001$

confirmed to influence the spread of fungicide (Gaskin et al. 2005; Abbott and Beckerman 2018).

It is possible that spray application method and its impact on leaf surface coverage could be over-looked in the application of fungicides or biologicals when treating myrtle rust. When there is poor fungicide coverage on adaxial or abaxial leave surfaces the control of myrtle rust becomes difficult (Pathan et al. 2020). It was reported that Metrosideros stems have a lower exposure area when fungicides are sprayed using a flat fan nozzle, including a difficult to wet abaxial leaf surface, making treatment of this species challenging (Gaskin et al. 2005). In the present study a spinning disc atomiser (Micromiser 5) was used together with an air-assisted spray application mechanism to ensure optimum coverage of fungicide on both leaf surfaces at a rate of $250 \mathrm{~L} / \mathrm{ha}$ based on recovered products on leaves of $M$. excelsa plants. Despite this, however, the infection levels on the abaxial surface were still higher. A similar observation was made by Pathan et al. (2020) who used a spray boom fitted with a flat-fan nozzle to apply fungicides from above the plant canopy. Although Pathan et al. (2020) reported severe infections on adaxial leaf surface for all treatments, infection scores were not done for both adaxial and abaxial leaf surfaces. On the contrary, the present study scored infections on both adaxial and abaxial leaf. The use of the spraying technique used in this study would provide a suitable platform to assess the efficacy of fungicides in future studies, ensuring that leaf or plant surface coverage is not an issue driving poor efficacy.

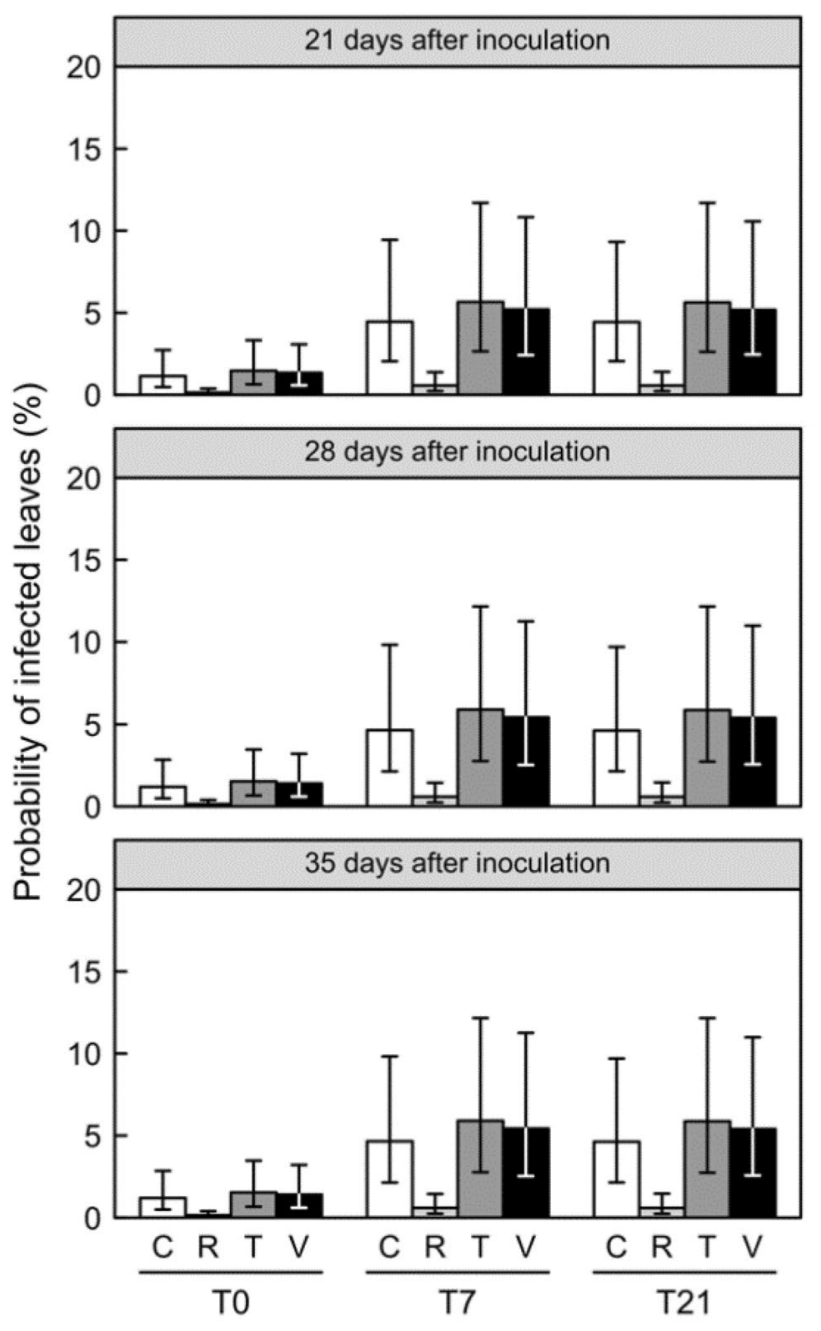

Fig. 5 Predicted probabilities from a generalised linear mixed effects model applied to the proportion of infected leaves at 21,28 and 35 days after inoculation (top, middle and bottom panels, respectively). $\mathrm{T} 0=$ inoculation at the same day of the fungicide application, $\mathrm{T} 7$ and $\mathrm{T} 21=$ inoculation at 7 and 21 days after fungicide application. Fungicide (a.i.) = Vandia (Triademinol), Timorex Gold (Natural extract of Melaleuca alternifolia), Radial (Azoxystrobin + Epoxiconazole). Fungicide treatments: $\mathrm{C}=\mathrm{Control}, \mathrm{R}=$ Radial + Adjuvant, $\mathrm{T}=$ Timorex Gold + Adjuvant, $\mathrm{V}=$ Vandia + Adjuvant. Error bars indicate standard errors for proportions of infected leaves

Although fungicide mixes were supplemented with an adjuvant in this study, A. psidii infection on the adaxial leaf surface was higher than the abaxial for all the fungicide treatments. The infection of the M. excelsa leaves progressed with time for all treatments with day 35 recording the highest date of leaf infection. This is congruent with Pathan et al.'s (2020) research where eight fungicides were used against the pathogen but without adjuvants. In the present study fungicide treated $M$. excelsa plants showed lower levels of leaf infection compared to the controls. However, comparatively azoxystrobin+ epoxiconazole had less 
Table 7 Results from a post-hoc analysis contrasting the fungicide treatments associated with the GLMM for the leaf infection data

\begin{tabular}{lclcl}
\hline Contrast & Estimate & SE & $\mathrm{t}$ & Padj \\
\hline $\mathrm{C}-\mathrm{R}$ & 2.10 & 0.89 & 2.35 & $0.038^{*}$ \\
$\mathrm{C}-\mathrm{T}$ & -0.25 & 0.83 & -0.30 & 0.914 \\
$\mathrm{C}-\mathrm{V}$ & -0.16 & 0.83 & -0.20 & 0.914 \\
$\mathrm{R}-\mathrm{T}$ & -2.35 & 0.89 & -2.65 & $0.033^{*}$ \\
$\mathrm{R}-\mathrm{V}$ & -2.26 & 0.89 & -2.55 & $0.033^{*}$ \\
$\mathrm{~T}-\mathrm{V}$ & 0.09 & 0.83 & 0.11 & 0.914 \\
\hline
\end{tabular}

${ }^{a}$ Estimate Estimated difference, ${ }^{b} \mathrm{SE}$ Standard error of the difference, ${ }^{c} t$ t-value (819 degrees of freedom), ${ }^{d}$ Padj Multiplicity adjusted P-value (Benjamini and Hochberg 1995)

${ }^{\mathrm{e}}$ Results are averaged over the levels of inoculation time and assessment dates. Results are given on the log odds ratio scale

Table 8 Likelihood ratio test results from a backwards selection procedure applied to a generalised linear mixed effect model (GLMM) testing the effects of inoculation time, fungicide treatment, assessment date and their interactions on the proportion of infected shoots

\begin{tabular}{llll}
\hline Dropped term & $\mathrm{L}$ & $\mathrm{df}$ & $\mathrm{P}$ \\
\hline First stage & & & \\
Inoculation time $\times$ Fungicide $\times$ Assessment date & 2.61 & 12 & 0.998 \\
Second stage & & & \\
Inoculation time $\times$ Fungicide & 7.36 & 6 & 0.288 \\
Inoculation time $\times$ Assessment date & 1.95 & 4 & 0.745 \\
Fungicide $\times$ Assessment date & 1.49 & 6 & 0.960 \\
Third stage & & & \\
Inoculation time & 9.36 & 2 & $0.009^{* *}$ \\
Fungicide & 9.38 & 3 & $0.025^{*}$ \\
Assessment date & 0.72 & 2 & 0.699 \\
\hline
\end{tabular}

${ }^{\mathrm{a}} \mathrm{L}=$ likelihood ratio statistic, ${ }^{\mathrm{b}} \mathrm{df}=$ degrees of freedom of the $\mathrm{L}$ statistic, ${ }^{c} \mathrm{P}=\mathrm{P}$-value. ${ }^{*} \mathrm{P}<0.05, * * \mathrm{P}<0.01$, $* * * \mathrm{P}<0.001$

infected plants throughout the study compared with natural extract of Melaleuca alternifolia and triadimenol. Similarly, Mueller and Robertson (2008) reported of a combination of the two active ingredients tends to work effectively and efficiently. Pathan et al. (2020) demonstrated azoxystrobin was one of the most effective active ingredients against $A$. psidii with Lophomyrtus $\times$ ralphii and $M$. excelsa as host-plants.

Azoxystrobin, a strobilurin, is reported to be a xylemsystemic compound (Godwin et al. 1999). In broad-leaved crops the movement of azoxystrobin to new growth areas occurred from initial spray deposition on the stem (Bartlett et al. 2002). However, further work has shown that movement of azoxystrobin to new growth areas was insufficient to provide robust disease control on subsequently emerging leaves (Bartlett et al. 2002). Strobilurins are best applied before infection or in the early stages of disease development (Bartlett et al. 2002; Ypema and Gold 1999) as they target the respiratory mechanisms of pathogens. According

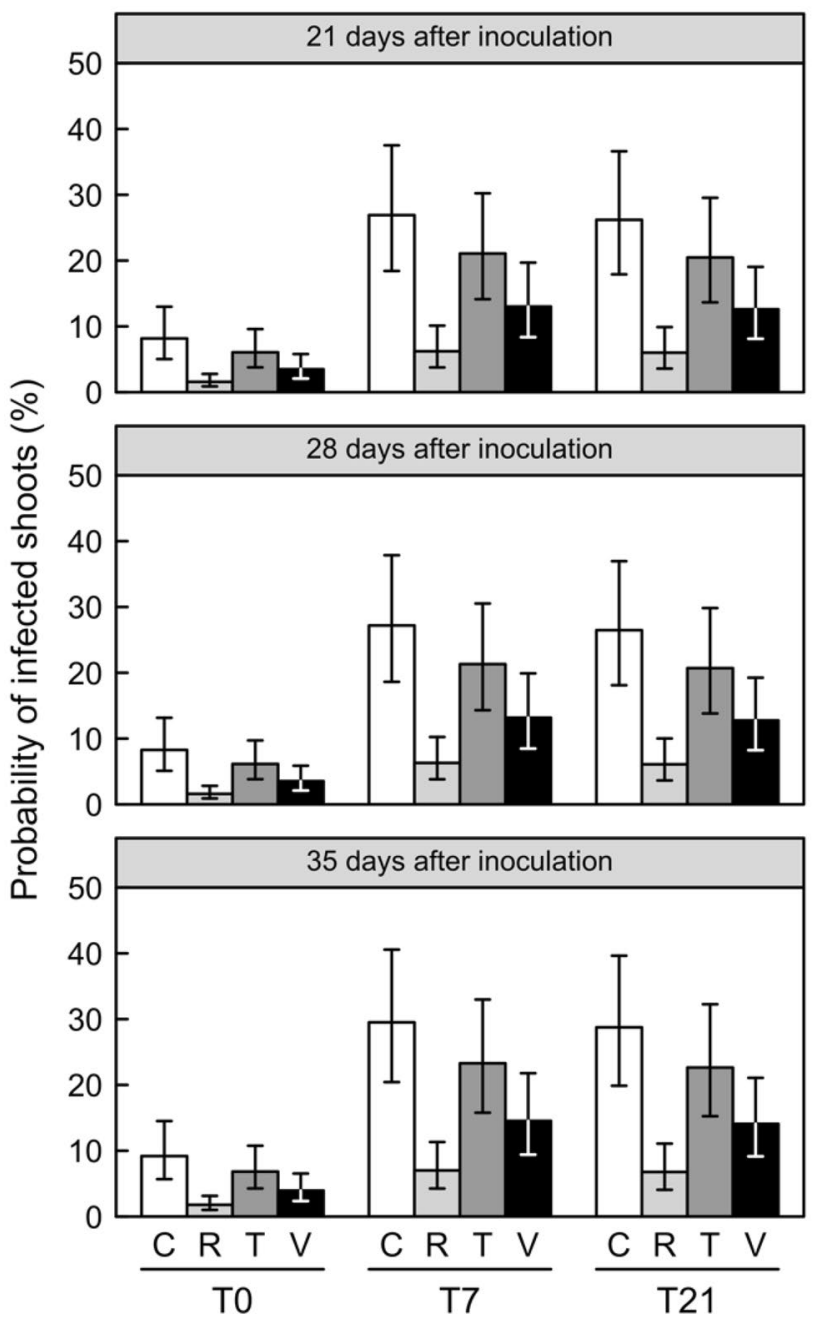

Fig. 6 Predicted probabilities from a generalised linear mixed effects model applied to the proportion of infected shoots at 21, 28 and 35 days after inoculation (top, middle and bottom panels, respectively). $\mathrm{T} 0=$ inoculation at the same day of the fungicide application, $\mathrm{T} 7$ and $\mathrm{T} 21=$ inoculation at 7 and 21 days after fungicide application. Fungicide (a.i.) = Vandia (Triademinol), Timorex Gold (Natural extract of Melaleuca alternifolia), Radial (Azoxystrobin +Epoxiconazole). Fungicide treatments: $\mathrm{C}=\mathrm{Control}, \mathrm{R}=$ Radial+Adjuvant, $\mathrm{T}=$ Timorex Gold +Adjuvant, $\mathrm{V}=$ Vandia + Adjuvant. Error bars indicate standard errors for proportion of infected shoots

Table 9 Results from a post-hoc analysis contrasting the fungicide treatments associated with the GLMM for the shoot infection data

\begin{tabular}{lllll}
\hline Contrast & Estimate & SE & $t$ & $P_{\text {adj }}$ \\
\hline T0 - T7 & -1.42 & 0.51 & -2.81 & $0.010^{*}$ \\
T0 - T21 & -1.38 & 0.51 & -2.73 & $0.010^{*}$ \\
T7 - T21 & 0.04 & 0.48 & 0.08 & 0.939 \\
\hline
\end{tabular}

${ }^{\mathrm{a}}$ Estimate Estimated difference, ${ }^{\mathrm{b}} \mathrm{SE}$ Standard error of the difference, ${ }^{\mathrm{c}} t=t$-value (277 degrees of freedom), ${ }^{\mathrm{d}} P_{\text {adj }}$ Multiplicity adjusted $P$ value (Benjamini \& Hochberg method 1995)

${ }^{\mathrm{e}}$ Results are averaged over the levels of fungicide treatment and assessment dates. Results are given on the log odds ratio scale 
to Reddy (2013), the most sought-after strobilurin is azoxystrobin because of its excellent toxicological profile. Triazoles, such as epoxiconazole used in the study are demethylation inhibitors (DMI), with systemic movement in plants, early accumulation in plant tissue, which act against fungal growth (Erincik et al. 2016). The triazoles have been reported to inhibit ergosterol biosynthesis and therefore do not prevent spore germination and early germ-tube development because the pathogen obtains a supply of ergosterol or its precursors from reserves within the spore (Godwin et al. 1999). Considering the different mechanisms by which the triazole and strobilurins function when applied, it is not surprising that the azoxystrobin + epoxiconazole mix was more effective than the natural extract of Melaleuca alternifolia and triademinol used in the present study. The effectiveness of strobilurins and triazole fungicide mixtures have been confirmed against myrtle rust in Eucalyptus species in several reports (Masson et al. 2011, 2013; Martins et al. 2014). To control many plant pathogens, multi-site fungicides are necessary (Hirooka and Ishii 2013) however consideration has to be made not to over-repeat applications of the same fungicide which could lead to fungicide resistance.

Triazoles such as triadimenol, tebuconazole and cyproconazole have been reported to be effective as stand-alone against myrtle rust in Eucalyptus grandis via preventative trials with application repeated every fourteen days (Zauza 2008; Masson et al. 2013). Martins et al. (2011) confirmed triadimenol as one of the best fungicides against myrtle rust in Psidium guajava with bi-weekly repeated applications, a finding that supported earlier trials (Demuner and Alfenas 1991; Ruiz et al. 1991; Alfenas et al. 2003; Alfenas 2004). On the contrary in the present study, triadimenol as stand-alone fungicide was applied once on $M$. excelsa plants prior to inoculation and was not effective. This indicates that the one-off fungicide application of triadimenol prior to infection was not enough to protect the M. excelsa plants against myrtle rust. However, Zauza (2008) recommends triadimenol for curative trials since it was effective when applied in later phases of the disease cycle and slowed the progress of myrtle rust infection.

The preventative trials in this current study has important implications to the management of A. psidii in New Zealand because for the first time a research trial has successfully developed myrtle rust inoculation assay under controlled conditions, tested three fungicides mixed with adjuvants, and designed a new spray mechanism for fungicide application. This research addresses a knowledge gap for the effective control and development of potential management strategies against myrtle rust in New Zealand.

Supplementary Information The online version contains supplementary material available at https://doi.org/10.1007/s41348-021-00523-1.
Acknowledgements We appreciate the immense support of Carolina Gous, John Meredith and Vanessa Cotterill, the technical staff in the Forest Protection-Pest Management Team at Scion. We also appreciate the support of Dr. Julia Soewarto, all the staff of Plant Protection Chemistry NZ Ltd $\left(\mathrm{PPC}_{\mathrm{NZ}}\right)$, Scion Forest Protection Team and Nursery Teams.

Funding This study was funded by the Ministry for Primary Industries (MPI) New Zealand.

\section{Declarations}

Conflict of interest The authors declare that they have no conflict of interest.

Ethical approval This article does not contain any studies with human participants or animals performed by authors.

Open Access This article is licensed under a Creative Commons Attribution 4.0 International License, which permits use, sharing, adaptation, distribution and reproduction in any medium or format, as long as you give appropriate credit to the original author(s) and the source, provide a link to the Creative Commons licence, and indicate if changes were made. The images or other third party material in this article are included in the article's Creative Commons licence, unless indicated otherwise in a credit line to the material. If material is not included in the article's Creative Commons licence and your intended use is not permitted by statutory regulation or exceeds the permitted use, you will need to obtain permission directly from the copyright holder. To view a copy of this licence, visit http://creativecommons.org/licenses/by/4.0/.

\section{References}

Abbott CP, Beckerman JL (2018) Incorporating adjuvants with captan to manage common apple diseases. Plant Dis 102:231-236

Alfenas AC, Maffia LA, Macabeu AJ, Sartorio RC (1993) Efficiency of triadimenol, oxycarboxin and diniconazole for rust (Puccinia psidii) control in coppice of Eucalyptus cloeziana under field conditions. Revista Arvore 17:247-263

Alfenas AC, Zauza EAV, Assis TF (2003) First record of Puccinia psidii on Eucalyptus globulus and E viminalis in Brazil. Australia Plant Path 32:325

Alfenas, A. C. (2004) Fungicidas indicados para o controle de doencas em viveiros florestals. In A. C. Alfenas, A. A. Valverde Zauza \& R. G. M. e. T. Francisco de A. (Eds.), Clonagem e doenças do eucalipto (pp. 226-227). Portugal: Livros

Bakke D (2007) Analysis of issues surrounding the use of spray adjuvants with herbicides. USDA, Washington, DC. https://www.fs. usda.gov/Internet/FSE_DOCUMENTS/fsbdev3_045552.pdf

Bartlett DW, Clough JM, Godwin JR, Hall AA, Hamer M, ParrDobrzanski B (2002) The strobilurin fungicides. Pest Manag Sci 58:649-662

Benjamini Y, Hochberg Y (1995) Controlling the false discovery rate: a practical and powerful approach to multiple testing. J R Stat Soc B 57:289-300

Beresford RM, Turner R, Tait A, Paul V, Macara G, Zhidong DY, Lima L, Martin R (2018) Predicting the climatic risk of myrtle rust during its first year in New Zealand. N z Plant Prot 71:332-347

Brooks MB, Kristensen K, van Benthem KJ, Magnusson A, Berg CW, Nielsen A, Skaug HJ, Maechler M, Bolker BM (2017) glmmTMB balances speed and flexibility among packages for zero-inflated generalized linear mixed modeling. The R Journal 9:378-400 
Buys MH, Flint HJ, Miller EM, Yao H, Caird AR, Ganley RJ (2016) Preparing for the invasion: efficacy of DNA barcoding to discern the host range of myrtle rust (Puccinia psidii) among species of Myrtaceae. Forestry 89:263-270

Carnegie AJ, Lidbetter JR (2012) Rapidly expanding host range for Puccinia psidii sensu lato in Australia. Australas Plant Pathol 41:13-29

Carnegie AJ, Lidbetter JR, Walker J, Horwood MA, Tesoriero L, Glen M, Priest MJ (2010) Uredo rangelii, a taxon in the guava rust complex, newly recorded on Myrtaceae in Australia. Australas Plant Pathol 39:463-466

Chang S, Soewarto J, Adusei-Fosu K, Rolando C, Ganley R, Padamsee M, Waipara N, Grant A, Wegner W, Gee M (2018) Potential disease control tools most likely to be effective against Austropuccinia psidii. Ministry of Primary Industries, New Zealand Report.

Chardón CE, Toro RA (1934) Mycological explorations of Venezuela. Contributions from the Department of Biology, University of Puerto Rico. 8:1-353.

Coutinho TA, Wingfield MJ, Alfenas AC, Crous PW (1998) Eucalyptus rust: A disease with the potential for serious international implications. Plant Dis 82:819-825

Demuner NL, Alfenas AC (1991) Fungicidas sistêmicos para o controle da ferrugem, causada por Puccinia psidii em Eucalyptus cloeziana. Fitopatol Brasil 16:173-176

Du Plessis E, McTaggart AR, Granados GM, Wingfield MJ, Roux J, Ali MIM, Pegg GS, Makinson J, Purcell M (2017) First report of myrtle rust caused by Austropuccinia psidii on Rhodomyrtus tomentosa (Myrtaceae) from Singapore. Plant Dis 101:1676

Erincik Ö, Daldal M, Özkul Y (2016) Efficacy and timing of application of fungicides for plum rust control in Turkey. Crop Prot 88:88-95

Ferrari JT, Nogueira EMD, dos Santos AJT (1997) Control of rust (Puccinia psidii) in guava (Psidium guajava). Acta Hort 452:55-57

Foy CL (1993) Progress and developments in adjuvant use since 1989 in the USA. Pestic Sci 38:65-76

Furtado EL, Moraes C (2011) Is aerial spraying efficient in the control of eucalyptus rust? Revista Campo \& Negócios 106:88-89

Ganley RJ, Beresford RM (2018) Confidential report: Myrtle rust. New Zealand, Ministry for Primary Industries (MPI), Crown Research Institutes (CRI)-SCION, Manaaki Whenua and Plant \& Food Research.

Gaskin RE, Steele KD, Forster WA (2005) Characterizing plant surfaces for spray adhesion and retention. N z Plant Prot 58:179-183

Gent HD, Schwartz HF, Nissen SJ (2003) Effect of commercial adjuvants on vegetable crop fungicide coverage, absorption, and efficacy. Plant Dis 87:591-597

Giblin F (2013) Myrtle rust report: New Caledonia. Assessment of myrtle rust situation in New Caledonia: 13(May), pp. 2013-17 May 2013 Maroochydore University of the Sunshine Coast. p Qld, Australia 18

Glen M, Alfenas AC, Zauza EAV, Wingfield MJ, Mohammed C (2007) Puccinia psidii: a threat to the Australian environment and economy a review. Australas Plant Pathol 36:1-16

Godwin JR, Bartlett DW, Heaney SP (1999) Azoxystrobin: implications of biochemical mode of action, pharmacokinetics and resistance management for spray programmes against Septoria diseases of wheat. In: Lucas JA, Bowyer P, Anderson HM (eds) In Septoria on cereals: a study of pathosystems. CABI, UK-Wallingford, pp 299-315

Goes AD, Martins RD, Reis RF (2004) Effect of copper fungicides sprayed alone or in combination with mancozeb, in expression of phytotoxicity symptoms and rust control caused by Puccinia psidii in guava. Rev Bras Frutic 26:237-240

Hirooka T, Ishii H (2013) Chemical control of plant diseases. J Gen Plant Pathol 79:390-401

Horwood M, Carnegie A, Park R, Hills WP (2013) Gathering efficacy data to identify the most effective chemicals for controlling myrtle rust (Uredo rangelii). Plant Health Australia: Canberra, Australia.

Junghans DT, Alfenas AC, Brommonschenkel SH, Oda S, Mello EJ, Grattapaglia D (2003) Resistance to rust (Puccinia psidii Winter) in Eucalyptus: mode of inheritance and mapping of a major gene with RAPD markers. Theor Appl Genet 108:175-180

Kawanishi T, Uematsu S, Kakishima M, Kagiwada S, Mamamoto H, Morie H, Namba S (2009) First report of rust disease on ohia and the causal fungus, Puccinia psidii, in Japan. J Gen Plant Pathol $75: 428-431$

Kern FD, Ciferri R, Thurston HW Jr (1933) The rust flora of Dominican Republic. Ann Mycol 31:1-40

Lenth R (2020) emmeans: Estimated Marginal Means, aka LeastSquares Means. R package version 1.5.0. https://CRAN.R-proje ct.org/package $=$ emmeans

Lenth R, Singmann H, Love J, Buerkner P, Herve M (2020) R Package 'emmeans' 1.4.4

Lindquist JC (1982) Royas de la Repu'blica Argentina y Zonas Lim-'trofes Buenos Aires, Argentina: Instituto Nacional de I Tecnología Agropecuaria. Colección Cientı́fica, 20:574.

MacLachlan JD (1938) A rust of the pimento tree in Jamaica, British West Indies. Phytopathology 28:157-170

Martins MVV, Silveira SF, Maffia LA, Rocabado JMA, Mussi-Dias V (2011) Chemical control of guava rust (Puccinia psidii) in the Northern Region of Rio de Janeiro State. Brazil Australas Plant Pathol 40:48-54

Martins MVV, Silveira SFd, Maffia LA (2014) Guava fruit loss caused by rust. Summa Phytopathologica 40:107-113

Masson MV, Moraes WB, Matos WC, Alves JM, Furtado EL (2011) Economic viability and efficiency in chemical control of eucalyptus rust under field conditions. Summa Phytopathologica 37:107-112

Masson MV, Moraes WB, Furtado EL (2013) Chemical control of eucalyptus rust: Brazilian experiences. In: Nita M, (ed) Fungicides - Showcases of Integrated Plant Disease Management from Around the World. Rijeka, InTech, p. 118-132.

May KR (1950) The measurement of airborne droplets by the magnesium oxide method. J Sci Instrum 27:128

McTaggart AR, Roux J, Granados GM, Gafur A, Tarrigan M, Santhakumar P, Wingfield MJ (2016) Rust (Puccinia psidii) recorded in Indonesia poses a threat to forests and forestry in South-East Asia. Australas Plant Pathol 45:83-89

Morin L, Aveyard R, Lidbetter JR, Wilson PG (2012) Investigating the Host-Range of the Rust Fungus Puccinia psidii sensu lato across Tribes of the Family Myrtaceae Present in Australia. Plos One $7: 35434$

Mueller DS, Robertson AE (2008) Preventative vs. curative fungicides. Integrated Crop Management News 798. Iowa State University, Ames, IA.

Pathan AK, Cuddy W, Kimberly MO, Adusei-Fosu K, Rolando CA, Park RF (2020) Efficacy of fungicides applied for protectant and curative activity against myrtle rust. Plant Dis 104:2123-2129

Percich JA, Nickelson LJ (1982) Evaluation of several fungicides and adjuvant materials for control of brown spot of wild rice. Plant Dis 66:1001-1003

Rayachhetry MB, Elliot ML, Van TK (1997) Natural epiphytotic of a rust fungus (Puccinia psidii) on Melaleuca quinquenervia in Florida. Plant Dis 81:831 
Reddy PP (2013) Bio-priming of Seeds. Recent Advances in Crop Protection. p 83-90.

Ross-Davis AL, Neves Graça R, Alfenas AC, Peever T, Hanna J, Uchida JY, Hauff RD, Kadooka C, Kim M-S, Cannon P, Namba S, Minato N, Simeto S, Pérez C, Rayamajhi M, Moran M, Lodge D, Arguedas M, Medel Ortiz R, Klopfenstein N (2013) Tracking the distribution of Puccinia psidii genotypes that cause rust disease on diverse myrtaceous trees and shrubs. In: Chadwick K (ed) Proceedings of the 61st Annual Western International Forest Disease Work Conference, 2013 October 6-11, Waterton Lakes National Park, Alberta, Canada. Western Forestry and Conservation Association. p. 131-137.

Roux J, Greyling I, Coutinho TA, Verleur M, Wingfield MJ (2013) The Myrtle rust pathogen, Puccinia psidii, discovered in Africa. Ima Fungus 4:155-159

Ruiz RAR, Alfenas AC, Demuner NL (1991) Efficiency of fungicides for the control of rust (Puccinia psidii) on guava (Psidium guajava). Summa Phytopathologica 17:147-153

Steurbaut W (1993) Adjuvants for use with foliar fungicides. Pestic Sci 38:85-91

Tessmann DJ, Dianese JC (2002) Hentriacontane: a leaf hydrocarbon from Syzygium jambos with stimulatory effects on the germination of uredósporos of Puccinia psidii. Fitopatol Bras 27:538-542
Thompson WM, Nissen SJ, Master RA (1996) Adjuvant effects on imazethapyr, 2,4-D and picloram absorption by leafy spurge (Euphorbia esula). Weed Sci 44:469-475

Uchida JY, Zhong S, Killgore E (2006) First report of a rust disease on ohia caused by Puccinia psidii in Hawaii. Plant Dis 90:524-524

Ypema HL, Gold RE (1999) Kresoxim methyl: -modification of a naturally occurring compound to produce a new fungicide. Plant Dis 83:4-19

Zabkiewicz JA (2000) Adjuvants and herbicidal efficacy-Present status and future prospects. Weed Res 40:139-149

Zauza EAV (2008) Eficiência de fungicidas sistêmicos no controle da ferrugem do eucalyptus. Revista Arvore 32:829-835

Publisher's Note Springer Nature remains neutral with regard to jurisdictional claims in published maps and institutional affiliations. 